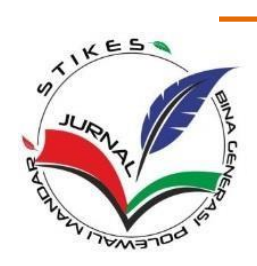

BINA GENERASI ; JURNAL KESEHATAN

EDISI 12 VOLUME (1) 2020

p- ISSN : 1979-150X ; e- ISSN: 2621-2919

Website : https://ejurnal.biges.ac.id/index.php/kesehatan/

Email : Ippmbiges@gmail.com

\title{
HUBUNGAN LINGKARKEPALA DENGAN PERKEMBANGAN MOTORIK PADA ANAK USIA 1-24 BULAN DI RUMAH SAKIT IBU DAN ANAK SITTI KHADIJAH 1 MUHAMMADIYAH MAKASSAR
}

\author{
Sunarti $^{1}$, Akbar Asfar ${ }^{2}$, Nadila Hafazi Alkatiri ${ }^{3}$ \\ ${ }^{1,2,3}$ Program Studi Ilmu Keperawatan Universitas Muslim Indonesia
}

Keywords:

Children,

Head

Circumference,

Fine Mototrics,

Rough Motorik

\begin{abstract}
Background: Infancy is a golden age (Golden Age) in the development of an individual. At the time of this child extraordinary growth and development both in terms of motor, logic, cognitive, and psychosocial. Children under five experience an increase in general developmental delay. Objective: This study was to determine the relationship of head circumference with motor development of children aged 1-24 months at the Sitti Khadijah 1 Muhammadiyah Hospital, Makassar. Method: The research design used was analytic observational using a cross sectional study approach. Where the design of this study in the form of measurement or observation of independent variables and dependent variables and observations of objects is only done once and at the same time. The determination of the sample is done by accidental sampling technique with a sample size of 142 children. Relationship test was performed using chisquare test with significance level $\alpha<0.05$. Result: The results showed that children with abnormal head circumference and fine motor development were inhibited as much as $9.2 \%$ with a value of $\rho=0,000$, this showed that there was a significant relationship between head circumference with fine motor development in children aged 1-24 months at the Mother Hospital and Anak Sitti Khadijah 1 Muhammadiyah Makassar. And children who have abnormal head circumference with impaired gross motor development as much as $9.9 \%$ with a value of $p=0,000$, this shows there is a significant relationship between head circumference with gross motor development in children aged 1-24 months at the Mother and Child Hospital Sitti Khadijah 1 Muhammadiyah Makassar. Conclusion: The conclusion from the results of this study found that there was a significant relationship between head circumference with fine motor development and there was a significant relationship between head circumference with gross motor development. Thus it is expected for parents to frequently take measurements of head circumference and screening of motor development in children to determine the development of their brain and detect any delay in motor development of children.
\end{abstract}




\section{PENDAHULUAN}

\section{Latar Belakang}

Masa bayi adalah masa emas (Golden Age) dalam perkembangan seorang individu. Pada masa ini anak mengalami tumbuh kembang yang luar biasa baik dari segi motorik, emosi, kognitif, maupun psikososial (Maryunani, 2010).

Istilah tumbuh kembang sebenarnya mencakup 2 peristiwa yang sifatnya berbeda, tetapi saling berkaitan dan sulit dipisahkan, yaitu pertumbuhan dan perkembangan. Dalam proses tumbuh kembang dimulai dari kepala ke seluruh anggota badan, misalnya mulai melihat, tersenyum, mengangkat badan, duduk, berdiri, dan seterusnya. Sedangkan untuk tercapainya tumbuh kembang yang optimal tergantung pada potensi biologiknya. Tingkat tercapainya potensi biologik seseorang merupakan hasil interaksi berbagai faktor yang saling berkaitan, yaitu faktor genetik, lingkungan bio-fisikopsiko-sosial dan perilaku. Proses yang unik dan hasil akhir yang berbeda-beda yang memberikan ciri tersendiri pada setiap anak (Soetjiningsih, 2010).

Pertumbuhan (growth) merupakan masalah perubahan dalam ukuran besar, jumlah, ukuran atau dimensi tingkat sel, organ maupun individu yang bisa diukur dengan ukuran berat (gram,kilogram), ukuran panjang (cm,meter). Sedangkan perkembangan (development) merupakan bertambah sempurnanya fungsi alat tubuh yang dapat dicapai melalui tumbuh kembang dan belajar,terdiri dari kemampuan gerak kasar dan halus, pendengaran, penglihatan, komunikasi, bicara, emosi-sosial, kemandirian, dan perkembangan moral (Muslihatun, 2010).

Perkembangan motorik diartikan sebagai perkembangan dari unsur kematangan dan pengendalian gerak tubuh dan perkembangan tersebut berhubungan erat dengan perkembangan motorik kasar di otak. Pada anak gerakan ini dibedakan dengan jelas antara gerakan kasar dengan gerakan halus. Pada usia $0-2$ tahun kemampuan perkembangan motorik kasar dan motorik halus sangat pesat dan luar biasa (Yuniarti, 2015).

Ikatan dokter anak Indonesia (IDAI) menyebutkan bahwa lebih dari 200 juta anak di bawah usia lima tahun gagal mencapai potensi mereka dalam perkembangan kognitif. Anakanak usia di bawah lima tahun di negara-negara berkembang banyak yang terpapar beberapa resiko diantaranya adalah kemiskinan, kurang gizi, kesehatan yang buruk, dan kurangnya stimulasi dari lingkungan rumah dimana hal tersebut dapat berpengaruh terhadap aspek perkembangan pada anak. Di Indonesia sendiri sekitar 5\% hingga $10 \%$ anak diperkirakan mengalami keterlambatan perkembangan. Namun, data angka kejadian keterlambatan perkembangan umum belum diketahui dengan pasti, tetapi dapat diperkirakan sekitar 1\% hingga 3\% anak dibawah umur lima tahun mengalami keterlambatan perkembangan umum (IDAI, 2013). Gangguan perkembangan balita yang masih sering dijumpai diantaranya, gangguan berbicara/bahasa, cerebral palsy, sindrom down, perawakan pendek, autisme, retardasi mental serta gangguan pemusatan perhatian dan hiperaktifitas (GPPH) (Depkes RI, 2012).

Menurut Soetjiningsih (2010) terdapat beberapa faktor yang dapat mempengaruhi tumbuh kembang anak seperti genetik, gizi, jenis kelamin,umur, penyakit kronis, hormon, dan perawatan kesehatan. Salah satu kelainan tumbuh kembang yang terjadi pada anak yaitu kelainan lingkar kepala, seperti mikrosefali (lingkar kepala lebih kecil dari normal) dan makrosefali (lingkar kepala lebih besar dari normal), hal ini sering disebabkan oleh hidrosefalus dan megalensefali.

Lingkar kepala mencerminkan volume intrakranial dan dipakai untuk menafsirkan pertumbuhan otak. Apabila otak tidak tumbuh normal maka kepala akan kecil. Sehingga pada lingkar kepala (LK) yang lebih kecil dari normal (mikrosefali), maka hal ini menunjukan adanya retardasi mental. Sebaliknya apabila terdapat penyumbatan pada aliran cairan serebrospinal pada hidrosefalus akan meningkatkan volume kepala, sehingga lingkar kepala lebih besar dari normal (Soetjiningsih, 2010).

Pada penelitian sebelumnya yang dilakukan oleh Anna Uswatun dan Annisa Wulandari tentang hubungan lingkar kepala dengan perkembangan anak di Posyandu Tlogowatu Kemalang Klaten. Dari 49 anak, hasil penelitian menunjukan bahwa ada hubungan antara lingkar kepala dengan perkembangan anak. Dimana sebagian besar lingkar kepala adalah normal sebanyak 37 anak $(75,5 \%)$ dan yang paling sedikit adalah mikrosefalus sebanyak 5 anak (10,2\%). Pada 
perkembangan anak diketahui hasil sebagian besar perkembangan anak adalah normal yaitu sebanyak 42 anak $(85,7 \%)$ sedangkan yang paling sedikit ialah questionable dan untestable memiliki jumlah yang sama yaitu masingmasing 2 anak $(4,1 \%)$ (Uswatun \& Wulandari, 2011).

Berdasarkan data kunjungan di poliklinik anak Rumah Sakit Ibu dan Anak Sitti Khadijah 1 Muhammadiyah Makassar pada tahun 2017 berjumlah 3918 anak, pada tahun 2018 jumlah pengunjung di poliklinik anak meningkat menjadi 4069 anak. Dan data awal pada tahun 2019 bulan januari didapatkan bahwa pengunjung di poliklinik anak Rumah Sakit Ibu dan Anak Sitti Khadijah 1 Muhammadiyah Makassar berjumlah 220 anak. Dan berdasarkan data lingkar kepala pada bayi yang baru lahir di kamar bayi Rumah Sakit Ibu dan Anak Sitti Khadijah 1 Muhammadiyah Makassar pada tahun 2019 bulan januari dari 333 bayi untuk lingkar kepala normal sekitar $80 \%$ dan lingkar kepala tidak normal sekitar 20\% ( Data rekam Medik Rumah Sakit Ibu dan Anak Sitti Khadijah 1 Muhammadiyah Makassar).

Berdasarkan observasi yang dilakukan dibeberapa Rumah Sakit didapatkan ada beberapa Rumah Sakit yang tidak melakukan pengukuran lingkar kepala pada anak usia 1-24 bulan. Dari beberapa Rumah Sakit tersebut, Rumah Sakit Sitti Khadijah 1 Muhammadiyah Makassar termasuk Rumah sakit yang tidak mengukur lingkar kepala pada anak usia 1-24 bulan. Dan berdasarkan data yang diperoleh didapatkan lebih banyak kunjungan anak di Rumah Sakit Sitti Khadijah 1 Muhammadiyah Makassar daripada beberapa Rumah Sakit lainnya. Berdasarkan data tersebut Sehingga peneliti tertarik untuk melakukan penelitian di Rumah Sakit Sitti Khadijah 1 Muhammadiyah Makassar.

Berdasarkan uraian singkat pada latar belakang, maka perlu di kaji mengenai "Hubungan Lingkar Kepala dengan Perkembangan Motorik pada Anak Usia $1-24$ Bulan di Rumah Sakit Ibu dan Anak Sitti Khadijah 1 Muhammadiyah Makassar".

\section{Rumusan Masalah}

Adapun yang menjadi rumusan masalah dalam penelitian ini adalah: "Apakah ada Hubungan Lingkar Kepala dengan Perkembangan Motorik pada Anak Usia 1 - 24
Bulan di Rumah Sakit Ibu dan Anak Sitti Khadijah 1 Muhammadiyah Makassar?

\section{Tujuan}

Tujuan penelitian ini adalah untuk: Mengetahui lingkar kepala pada anak usia 1 24 bulan di Rumah Sakit Ibu dan Anak Sitti Khadijah 1 Muhammadiyah Makassar, Mengetahui perkembangan motorik Kasar pada anak usia 1 - 24 bulan di Rumah Sakit Ibu dan Anak Sitti Khadijah 1 Muhammadiyah Makassar, Mengetahui perkembangan motorik halus pada anak usia $1-24$ bulan di Rumah Sakit Ibu dan Anak Sitti Khadijah 1 Muhammadiyah Makassar, Mengetahui hubungan lingkar kepala dengan perkembangan motorik Kasar pada anak usia $1-24$ bulan di Rumah Sakit Ibu dan Anak Sitti Khadijah 1 Muhammadiyah Makassar dan Mengetahui hubungan lingkar kepala dengan perkembangan motorik halus pada anak usia $1-24$ bulan di Rumah Sakit Ibu dan Anak Sitti Khadijah 1 Muhammadiyah Makassar.

\section{METODE \\ Jenis Penelitian}

Jenis penelitian yang digunakan adalah analitik dengan desain cross sectional.

\section{Lokasi dan Waktu Penelitian}

Penelitian ini dilaksanakan di Rumah Sakit Ibu dan Anak Sitti Khadijah 1 Muhammadiyah Makassar. Penelitian ini dilaksanakan pada tanggal 08 Juli - 22 juli 2019.

\section{Populasi dan Sampel.}

Populasi dalam penelitian ini adalah seluruh anak yang berkunjung untuk memeriksakan diri pada awal tahun 2019 tepatnya bulan Januari yang berjumlah 220 anak di Rumah Sakit Ibu dan Anak Sitti Khadijah 1 Muhammadiyah Makassar. Sampel yang digunakan sebanyak 142 anak yang berusia $1-24$ bulan sesuai kriteria penelitian.

\section{Pengumpulan Data}

Pengumpulan data terdiri dari data primer data sekunder dengan menggunakan lembar observasi langsung atau skala Gutman. Data primer diperoleh melalui pengukuran antropometri dan pengukuran DDST dari sampel yang memenuhi kriteria penelitian. Cara pengukuran antropometri yaitu alat pengukur dilingkarkan pada anak melewati dahi, menutup 
alis mata, di atas kedua telinga, dan bagian kepala yang menonjol, tarik agak kencang, Baca angka pada pertemuan dengan angka 0 , Tanyakan tanggal lahir bayi/anak, hitung umur bayi/anak, Hasil pengukuran dicatat pada grafik lingkar kepala menurut umur dan jenis kelamin anak. Kriteria penilaian terdiri dari Normal; Apabila ukuran lingkar kepala anak pada usia 112 bulan (bayi) 34-48,5 $\mathrm{cm}$ dan usia 13-24 bulan (todler) 43,5-49 cm, Abnormal; Apabila ukuran lingkar kepala anak pada usia 1-12 bulan (bayi) $<34 \mathrm{~cm}$ atau $\geq 48,5 \mathrm{~cm}$ dan usia $13-24$ bulan (todler) $<43,5 \mathrm{~cm}$ atau $\geq 49 \mathrm{~cm}$.

Sedangkan pengukuran DDST dilakukan dengan cara menentukan umur anak pada saat pemeriksaan, menarik garis pada lembar DDST II sesuai dengan umur yang telah ditentukan, lakukan pengukuran pada anak tiap komponen dengan batasan garis yang ada mulai dari motorik kasar, bahasa, motorik halus, dan personal social dan Tentukan hasil penilaian apakah normal, meragukan, dan abnormal.

Data sekunder diperoleh dari informasi yang diberikan oleh Rumah Sakit Ibu dan Anak Sitti Khadijah 1 Muhammadiyah Makassar.

\section{Pengolahan dan Analisis Data}

Pengolahan data dilakukan dengan teknik Editing, coding, Entri dan Cleaning Data. Sedangkan analisa data terdiri dari analisa Univariat dan Analisa Bivariat. Selain itu penelitian ini juga melihat distribusi karakteristik yang dianggap terkait dengan kriteria sampel penelitian. Analisa data yang digunakan yaitu analisis chi-square dengan tingkat kemaknaan $\alpha=0.05$ menggunakan bantuan program komputer.

\section{HASIL}

Penelitian ini dilaksanakan di Rumah Sakit Ibu dan Anak Sitti Khadijah 1 Muhammadiyah Makassar pada tanggal 8 Juli sampai 22 Juli 2019, bertujuan untuk mengetahui hubungan lingkar kepala dengan perkembangan motorik pada anak usia 1-24 bulan di Rumah Sakit Ibu dan Anak Sitti Khadijah 1 Muhammadiyah Makassar. Besar sampel diambil menggunakan Accidental Sampling dengan pendekatan Cross Sectional serta menggunakan metode Observasional Analitik dimana sampel yang diperoleh yaitu sebanyak 142 Anak. Data yang didapatkan berupa data primer yang diperoleh dari pengukuran lingkar kepala dan penilaian perkembangan motorik yang menggunakan DDST. Data yang diperoleh kemudian diolah dengan menggunakan program komputer, yaitu mulai dari editing, koding, tabulasi dan analisa data sampai penyajian data. Dari hasil pengolahan data, disajikan dalam bentuk distribusi frekuensi karakteristik responden (analisa univariat) dan melihat hubungan variabel independen dan variabel dependen (analisa bivariat).

Tabel 1. Distribusi Frekuensi Berdasarkan Karakteristik Umur, Jenis Kelamin dan Jenis Persalinan pada anak Usia 1-24 Bulan di Rumah Sakit Ibu dan Anak Sitti Khadijah 1 Muhammadiyah Makassar

\begin{tabular}{|c|c|c|}
\hline Karakteristik & \multicolumn{2}{|c|}{ Jumlah } \\
\hline Umur & & \\
\hline $1-12$ bulan (bayi) & 102 & 71,8 \\
\hline 13-24 bulan (todler) & 40 & 28,2 \\
\hline Total & 142 & 100,0 \\
\hline Jenis Kelamin & & \\
\hline Laki-laki & 67 & 47,2 \\
\hline Perempuan & 75 & 52,8 \\
\hline Total & 142 & 100,0 \\
\hline Jenis Persalinan & & \\
\hline Normal & 89 & 62,7 \\
\hline Caesar & 53 & 37,3 \\
\hline Total & $\overline{142}$ & 100,0 \\
\hline
\end{tabular}


Berdasarkan Tabel 1 diperoleh data karakteristik responden berdasarkan umur bahwa sebagian besar anak berumur $1-12$ bulan yaitu sebanyak $71,8 \%$ dan sebagian kecil berumur $13-24$ bulan yaitu sebanyak $28,2 \%$, berdasarkan jenis kelamin bahwa sebagian besar anak berjenis kelamin laki laki yaitu sebanyak 47,2\% dan anak yang berjenis kelamin perempun sebanyak $52,8 \%$ dan berdasarkan data jenis persalinan bahwa sebagian besar anak yang dilahirkan secara normal yaitu sebanyak $62,7 \%$. dan anak yang dilahirkan secara caesar yaitu sebanyak $37.3 \%$.

Tabel 2. Distribusi Berdasarkan Lingkar Kepala, Perkembangan Motorik Kasar dan Perkembangan Motorik Halus pada Anak Usia 1-24 Bulan di Rumah Sakit Ibu dan Anak Sitti Khadijah 1 Muhammadiyah Makassar Tahun 2019

\begin{tabular}{|c|c|}
\hline Karakteristik & n \\
\hline \multicolumn{2}{|l|}{ Lingkar Kepala } \\
\hline $\begin{array}{l}\text { Normal } \\
\text { Abnormal }\end{array}$ & $\begin{array}{c}128 \\
14\end{array}$ \\
\hline \multicolumn{2}{|l|}{ Perkembangan Motorik Halus } \\
\hline $\begin{array}{l}\text { Tidak Terhambat } \\
\text { Terhambat }\end{array}$ & $\begin{array}{c}129 \\
13\end{array}$ \\
\hline \multicolumn{2}{|l|}{ Perkembangan Motorik Kasar } \\
\hline $\begin{array}{l}\text { Tidak Terhambat } \\
\text { Tehambat }\end{array}$ & $\begin{array}{c}128 \\
14\end{array}$ \\
\hline Total & 142 \\
\hline Total & 142 \\
\hline
\end{tabular}

Berdasarkan tabel 5.2 diperoleh data lingkar kepala bahwa sebagian besar anak memiliki lingkar kepala normal yaitu sebanyak $90,1 \%$,dan anak yang memiliki lingkar kepala abnormal sebanyak 9,9\%. Pada data perkembangan motorik halus didapatkan bahwa sebagian besar anak memiliki perkembangan motorik halus tidak terhambat yaitu sebanyak
$90,8 \%$, dan anak yang memiliki perkembangan motorik halus terhambat yaitu sebanyak $9,2 \%$ dan pada data perkembangan motorik kasar diperoleh data bahwa sebagian besar anak memiliki perkembangan motorik kasar tidak terhambat yaitu sebanyak $90,1 \%$ dan anak yang memiliki perkembangan motorik kasar terhambat yaitu sebanyak $9,9 \%$.

Tabel 3. Hubungan Lingkar Kepala dengan Perkembangan Motorik Halus pada Anak Usia 1-24 Bulan di Rumah Sakit Ibu dan Anak Sitti Khadijah 1 Muhammadiyah Makassar

\begin{tabular}{lccccccc}
\hline \multirow{3}{*}{ Lingkar kepala } & \multicolumn{4}{c}{ Perkembangan Motorik Halus } & \multirow{2}{*}{ Jumlah } & \multirow{2}{*}{$\boldsymbol{\rho}=$ value } \\
\cline { 2 - 6 } & \multicolumn{2}{c}{ Tidak Terhambat } & \multicolumn{3}{c}{ Terhambat } & & \\
\cline { 2 - 6 } & $\mathbf{n}$ & $\mathbf{\%}$ & $\mathbf{n}$ & $\mathbf{\%}$ & $\mathbf{n}$ & $\mathbf{\%}$ & \\
\hline Normal & 128 & 90,1 & 0 & 0 & 128 & 90,1 & 0 \\
Abnormal & 1 & 0,7 & 13 & 9,2 & 14 & 9,9 & \\
Total & 129 & 90,8 & 13 & 9,2 & 142 & 100 & \\
\hline
\end{tabular}

Berdasarkan tabel 4. menunjukan bahwa sebagian besar anak memiliki lingkar kepala normal dengan perkembangan motorik halus tidak terhambat sebanyak $90,1 \%$, anak yang yang memiliki lingkar kepala normal dan perkembangan motorik halus terhambat tidak 
temukan dan anak yang lainnya memiliki lingkar kepala abnormal dengan perkembangan motorik halus tidak terhambat sebanyak $0,7 \%$, serta anak yang memiliki lingkar kepala abnormal dengan perkembangan motorik halus terhambat sebanyak 9,2\%. Hasil uji statistik dengan menggunakan uji chi-squaretests diperoleh nilai $\rho=0.000$ lebih kecil dari nilai $\alpha$ $=0,005$, dengan demikian hasil perhitungan tersebut menujukan bahwa terdapat hubungan yang signifikan antara lingkar kepala dengan perkembangan motorik halus pada anak usia 124 bulan di Rumah Sakit Ibu dan Anak Sitti Khadijah 1 Muhammadiyah Makassar.

Tabel 4. Hubungan Lingkar Kepala dengan Perkembangan Motorik Kasar pada Anak Usia 124 bln di Rumah Sakit Ibu dan Anak Sitti Khadijah 1 Muhammadiyah Makassar

\begin{tabular}{lccccccc}
\hline \multirow{2}{*}{ Lingkar kepala } & \multicolumn{4}{c}{ Perkembangan Motorik Kasar } & \multirow{2}{*}{ Jumlah } & \multirow{2}{*}{$\boldsymbol{p}=$ value } \\
\cline { 2 - 7 } & \multicolumn{2}{c}{ Tidak terhambat } & \multicolumn{2}{c}{ Terhambat } & & \\
\cline { 2 - 7 } & $\mathrm{n}$ & $\%$ & $\mathrm{n}$ & $\%$ & $\mathrm{n}$ & $\%$ & \\
\hline Normal & 128 & 90,1 & 0 & 0 & 128 & 90,1 & \multirow{2}{*}{0,000} \\
Abnormal & 0 & 0 & 14 & 9,9 & 14 & 9.9 & \\
Total & 128 & 90.1 & 14 & 9,9 & 142 & 100 & \\
\hline
\end{tabular}

Berdasarkan tabel 4. Menunjukan bahwa sebagian besar anak memiliki lingkar kepala normal dengan perkembangan motorik kasar tidak terhambat sebanyak $90,1 \%$, anak yang yang memiliki lingkar kepala normal dan perkembangan motorik Kasar terhambat tidak temukan dan anak yang lainnya memiliki lingkar kepala abnormal dan dengan perkembangan motorik kasar tidak terhambat juga tidak ditemukan, serta anak yang memiliki

\section{PEMBAHASAN}

\section{Hubungan Lingkar Kepala dengan perkembangan Motorik Halus pada Anak Usia 1-24 Bulan di Rumah sakit Ibu dan Anak Sitti Khadijah 1 Muhammadiyah Makassar.}

Dari hasil analisa data menggunakan uji statistik chi-square antara variabel lingkar kepala dan variabel perkembangan motorik halus pada 142 anak usia 1-24 bulan di Rumah Sakit Ibu dan Anak Sitti Khadijah 1 Muhammadiyah Makassar di peroleh nilai $\mathrm{p}=$ 0,000 , dimana $(\alpha<0,05)$ dengan demikian menunjukan bahwa terdapat hubungan yang signifikan antara lingkar kepala dengan perkembangan motorik halus pada anak usia 124 bulan di Rumah Sakit Ibu dan Anak Sitti Khadijah 1 Muhammadiyah Makassar. Dimana dapat ditentukan dari normal tidaknya lingkar kepala pada persalinan normal, dimana dapat dibuktikan dengan jumlah anak yang lahir dengan persalinan normal sebanyak $89(62,7 \%)$ lingkar kepala abnormal dengan perkembangan motorik kasar terhambat sebanyak 9,9\%. Hasil uji statistik dengan menggunakan uji chisquaretests diperoleh nilai $\rho=0.000$ lebih kecil dari nilai $\alpha=0,005$, dengan demikian hasil perhitungan tersebut menujukan bahwa terdapat hubungan yang signifikan antara lingkar kepala dengan perkembangan motorik kasar pada anak usia 1-24 bulan di Rumah Sakit Ibu dan Anak Sitti Khadijah 1 Muhammadiyah Makassar.

anak. Dimana anak yang lahir secara persalinan normal cenderung perkembangan motorik halusnya tidak terhambat. Meskipun ada anak yang lahir dengan persalinan caesar sebanyak $53(37,3 \%)$ anak. Dimana anak yang biasanya lahir dengan jenis persalinan secara caesar cenderung memiliki lingkar kepala abnormal dan perkembangan motorik halusnya terhambat. Adapun asumsi peneliti berdasarkan hasil penelitian dimana anak yang memiliki lingkar kepala normal rata-rata mampu melakukan kegiatan motorik halus dan anak yang memiliki lingkar kepala abnormal tidak mampu melakukan kegiatan motorik halus. Hal ini dapat dibuktikan dengan hasil pengamatan peneliti anak yang memiliki lingkar kepala abnormal tidak mampu melakukan kegiatan seperti mengambil manik-manik dengan ibu jari dan jari, memindahkan kubus dari satu tangan ke tangan yang lainnya, mencoret-coret menggunakan pensil/pulpen, dan meniru menggoyangkan ibu jari.

Hasil penelitian ini sejalan dengan penelitian (Sabaria, Farsida, \& Parameswari, 
2019) mengatakan bahwa terdapat hubungan yang bermakna antara lingkar kepala dengan motorik halus dimana terdapat 73 anak yang terdiri dari $4,1 \%$ anak yang memiliki lingkar kepala makrosefal, 2,7\% anak yang memiliki lingkar kepala mikrosefal dan 93,2\% anak yang memiliki lingkar kepala normal. Hal ini menunjukan terdapat hubungan antara lingkar kepala dengan perkembangan motorik halus dengan nilai $\mathrm{p}=0,035$. Dan hasil penelitian ini juga sejalan dengan penelitian (Wulandari, 2011) mengatakan bahwa terdapat hubungan lingkar kepala dengan perkembangan anak dimana terdapat 41 anak yang terdiri dari $69,4 \%$ lingkar kepala normal dengan perkembangan motorik normal dan 10,2\% mikrosefal dengan perkembangan anak terhambat dengan nilai $\mathrm{p}=0,024(\alpha<0,05)$ yang berarti ada hubungan yang signifikan antara lingkar kepala dan perkembangan anak. Hasil penelitian ini berbanding terbalik dengan penelitian yang dilakukan oleh (Atmaja, 2016) yang menyatakan bahwa tidak ada hubungan lingkar kepala dengan perkembangan motorik halus dengan nilai $\mathrm{p}=0,978$.

Penelitian ini diperkuat dengan teori yang dikemukakan oleh Soetjiningsih (2010) bahwa lingkar kepala mencerminkan volume intrakranial dan dipakai untuk mentaksir pertumbuhan otak. Apabila otak tidak tumbuh normal maka kepala akan kecil. Sehingga pada lingkar kepala (LK) yang lebih kecil dari normal (mikrosefali), maka hal ini menunjukan adanya retardasi mental. Sebaliknya apa bila terdapat penyumbatan pada aliran cairan serebrospinal pada hidrosefalus akan meningkatkan volume kepala, sehingga lingkar kepala lebih besar dari normal.

Penelitian ini juga diperkuat oleh teori yang dikemukakan Tedjasaputra (2010) bahwa motorik merupakan pengendalian gerakan tubuh melalui kegiatan yang terkoordinir antara susunan saraf otak dan spinal cord. Motorik halus adalah gerakan yang menggunakan otototot halus atau sebagian antara tubuh tertentu, yang dipengaruhi oleh kesempatan untuk belajar dan berlatih misalnya, kemampuan memindahkan benda dari tangan, mencoretcoret, menyusun balok, menggunting, dan sebagaiannya.
Hubungan Lingkar Kepala dengan Perkembangan Motorik Kasar pada Anak Usia 1-24 Bulan di Rumah Sakit Ibu dan Anak Sitti Khadijah 1 Muhammadiyah makassar.

Dari hasil analisa data menggunakan uji statistik chi-square antara variabel lingkar kepala dan variabel perkembangan motorik kasar pada 142 anak usia 1-24 bulan di Rumah Sakit Ibu dan Anak Sitti Khadijah 1 Muhammadiyah Makassar di peroleh nilai $\mathrm{p}=$ $0,000,(\alpha<0,05)$ dengan demikian menunjukan bahwa terdapat hubungan yang signifikan antara lingkar kepala dengan perkembangan motorik kasar pada anak usia 1-24 bulan di Rumah Sakit Ibu dan Anak Sitti Khadijah 1 Muhammadiyah Makassar. Dimana dapat ditentukan dari normal tidaknya lingkar kepala pada persalinan normal, dimana dapat dibuktikan dengan jumlah anak yang lahir dengan persalinan normal sebanyak $89(62,7 \%)$ anak. Dimana anak yang lahir secara persalinan normal cenderung perkembangan motorik kasarnya tidak terhambat. Meskipun ada anak yang lahir dengan persalinan caesar sebanyak $53(37,3 \%)$ anak. Dimana anak yang biasanya lahir dengan jenis persalinan secara caesar cenderung memiliki lingkar kepala abnormal dan perkembangan motorik kasarnya terhambat. Adapun asumsi peneliti berdasarkan hasil penelitian, dimana anak yang memiliki lingkar kepala normal rata-rata mampu melakukan kegiatan motorik kasar dan anak yang memiliki lingkar kepala abnormal tidak mampu melakukan kegiatan motorik kasar. Hal ini dapat dibuktikan dengan hasil pengamatan peneliti anak yang memiliki lingkar kepala abnormal tidak mampu melakukan kegiatan seperti mengangkat kepala, membalikan badan, duduk, berdiri, dan membungkuk kemudian berdiri

Hasil penelitian ini sejalan dengan penelitian (Sabaria, Farsida, \& Parameswari, 2019) mengatakan bahwa terdapat hubungan yang bermakna antara lingkar kepala dengan motorik kasar dimana terdapat 73 anak yang terdiri dari $4,1 \%$ anak yang memiliki lingkar kepala makrosefal dengan perkembangan motorik kasar terhambat, 2,7\% anak yang memiliki lingkar kepala mikrosefal dengan perkembangan motorik kasar terhambat dan 93,2\% anak memiliki lingkar kepala normal. Hal ini menunjukan terdapat hubungan antara 
lingkar kepala dengan perkembangan motorik kasar dengan nilai $\mathrm{p}=0,001$. Dan menurut (Atmaja, 2016) mengatakan bahwa terdapat adanya hubungan antara lingkar kepala dengan perkembangan motorik kasar $\mathrm{p}=0,035$.

Penelitian ini juga diperkuat oleh teori yang dikemukakan Soetjiningsih (2010) bahwa Lingkar kepala berkaitan dengan perkembangan otak yang merupakan salah satu organ pengendali motorik. Perkembangan motorik yang terlambat dapat disebabkan oleh hal-hal tertentu seperti faktor keturunan dan faktor lingkungan. Faktor keturunan dimana pada keluarga rata-rata perkembangan motorik lambat dan faktor lingkungan pula seperti anak tidak kesempatan untuk belajar karena terlalu dimanjakan, selalu digendong atau diletakan di baby walker terlalu lama dan juga mengalami deprivasi menternal. Perkembang motorik beriringan dengan proses pertumbuhan secara genetik atau kemantangan fisik anak

Berdasarkan hasil penelitian maka pengukuran lingkar kepala dan screening perkembangan motorik anak sebaiknya sering dilakukan pada periode bayi yaitu untuk mengetahui perkembangan otaknya serta dapat dengan cepat mendeteksi adanya kelainan pada anak serta keterlambatan pada perkembangan motoriknya.

\section{KESIMPULAN DAN SARAN}

Berdasarkan hasil penelitian dan pembahasan dapat disimpulkan bahwa: Sebagian besar anak usia 1-24 bulan memiliki lingkar kepala normal sebanyak 90,1\% dan anak yang memiliki lingkar kepala abnormal sebanyak 9,9\%, Sebagian besar anak usia 1-24 bulan memiliki perkembangan motorik halus tidak terhambat sebanyak 90,8\% dan anak yang memiliki perkembangan motorik halus terhambat yaitu sebanyak $9,2 \%$, Sebagian besar anak usia 1-24 bulan memilki perkembangan motorik kasar normal sebanyak 90,1\% dan anak yang memiliki perkembangan motorik kasar abnormal yaitu sebanyak 9,9\%, ada hubungan signifikan antara lingkar kepala dengan perkembangan motorik halus pada anak usia 1-24 bulan di Rumah Sakit Ibu dan Anak Sitti Khadijah 1 Muhammadiyah Makassar dengan nilai $\rho=0,000$ dan ada hubungan signifikan antara lingkar kepala dengan perkembangan motorik kasar pada anak usia 1-
24 bulan di Rumah Sakit Ibu dan Anak Sitti Khadijah 1 Muhammadiyah Makassar dengan nilai $\rho=0,000$.

\section{DAFTAR PUSTAKA}

Ariesta. 2008. Perbedaan Status Gizi dan Perkembangan Anak Balita yang Dibesarkan di Panti Asuhan dengan yang Dibesarkan di Lingkungan Keluarganya di Surakarta. Fakultas Kedokteran Universitas Sebelas Maret Surakarta. FK UMS Surakarta.

Atmaja, P. Y. (2016). Hubungan lingkar kepala dengan perkembangan motorik bayi di kecamatan ceper kabupaten Klaten. Universitas Sebelas Maret, IV.

Depkes RI. (2012). Pedoman Pelaksanaan Stimulasi Deteksi dan Intervensi Tumbuh Kembang Anak. Dep.Kes.(Diakses tanggal 10 maret 2019 dari http://www.DepkesRI.com)

Depkes RI. (2010). Stimulasi Deteksi dan Intervensi Dini Tumbuh Kembang.(Diakses tanggal 11 maret 2019 dari http://www.DepkesRI.com)

Dzuhrisal. (2012). Perbedaan Bekerja dan Tidak Bekerja Terhadap Hasil Perkembangan Balita.

Hurlock, E. B. (2009). Perkembangan Anak.Jakarta.Erlangga.

Hidayat, A.A. (2012). Pengantar Ilmu Keperawatan Anak 1. Jakarta: Salemba Medika.

IDAI No: 003/Rek/PP IDAI/2014. (2014). Pemantauan Lingkar Kepala dan UbunUbun Besar.

IDAI. (2013). Mengenal Keterlambatan Perkembangan Umum pada bayi.

Indrawati, D. R. (2016). Hubungan Status Gizi dan Lingkar Kepala Dengan Kemampuan Motorik Kasar Anak Usia 1-2 Tahun. Journal of Nutrition College .

KNEPK. (2007). Pedoman Etik Internasional Untuk Penelitian Biomedis yang Melibatkan Manusia; Komisi Nasional Etik Penelitian Kesehatan, (online), (http://www.knepk.litbang.depkes.go.id/k nepk.pdf, diakses 26 Maret 2019).

Maryunani, A. (2010). Ilmu Kesehatan Anak dalam Kebidanan. Jakarta: TIM.

Maryunis, Asnaniar, W. O., Agustini, T., Mappanganro, A., Safruddin, Munir, N. W., et al. (2019). Panduan Penulisan Proposal Penelitian dan Skripsi. 
Makassar: PSIK UMI.

Matondang dkk. (2009). Diagnosis Fisis pada Anak. Jakarta: CV Sagung Seto.

Muslihatun, W. N. (2010). Asuhan Neonatus bayi dan Balita. Yogyakarta: Fitramaya.

Narendra, M. B., Sularyo, T. S., Soetjiningsih, \& Suyitno, H. (2002). Tumbuh Kembang Anak dan Remaja. Jakarta: CV. Sagung Seto.

Nursalam. (2015). Metodologi Penelitian Ilmu Keperawatan Pendekatan Praktis. Jakarta: Salemba Medika.

Nursalam, Susilaningrum, R., \& Utami, S. (2005). Asuhan Keperawatan Bayi dan Anak (untuk perawat dan bidan) . Jakarta: Salemba Medika.

Sabaria, R., Farsida, \& Parameswari, I. (2019). Hubungan lingkar kepala dengan perkembangan anak Usia 12-36 bulan berdasarkan skala denver development sceering test-II (DDST-II) Posyandu RW ) 03 Mustika Jaya Bekasi Timur. Jurnal Kedokteran dan Kesehatan , 15 (1), 46.

Siswono. 2008. Jaringan Informasi Pangan dan Gizi. Volume XIV. Jakarta: Ditjen Bina Gizi Masyarakat.

Soetjiningsih. (2010). Tumbuh Kembang Anak.
Jakarta: EGC

Sujono R. \& Sukarmin (2012). Asuhan Keperawatan pada Anak. Yogyakarta: Graha Ilmu.

Suyanto. (2011). Metode dan Aplikasi Keperawatan. Yogyakarta: Nuha Medika.

Tedjasaputra, M., 2009. Perkembangan Anak Usia Dini. Jakarta: EGC

Utami, S. H., B. W., \& Pamungkasari, E. P. (2018). Hubungan Pemberian Asi Ekslusif dan Lingkar Kepala Dengan Perkembangan Motorik Bayi Usia 6-12 Bulan di Surakarta. Smart Medical Journal , 1 (2), 1.

Wiyani. (2014). Psikologi Perkembangan Anak Usia Dini Panduan Bagi Orangtua dan Pendidik PAUD dalam Memahami dan Mendidik Anak Usia Dini. Yogyakarta: Gava Medika.

Wulandari, A. U. (2011). Hubungan Lingkar Kepala dengan perkembangan Anak Usia 12-24. Jurnal Involusi Kebidanan, 39.

Yuniarti, S. (2015). Asuhan Tumbuh Kembang Neonatus Bayi Balita dan Anak Pra Sekolah . Bandung: PT Refika Aditama. 